\title{
MACHINE LEARNING APPLICATIONS ON SOIL GEOCHEMISTRY IN MAPPING STRATIGRAPHY TO IMPROVE PROJECT-SCALE MAPS IN MINERAL EXPLORATION - KIPUSHI AREA CASE STUDY, ZAMBIA
}

MUNSHYA ZIMBA, BUBILE NKHATA AND GHISLAIN KABUNDA

First Quantum Minerals

Presenting Author: Munshya.Zimba@fqml.com

First Quantum Minerals' Kipushi Exploration Project is located in North-Western Province of Zambia near the border with the Democratic Republic of Congo (DRC), and adjacent to the world-class Kipushi $\mathrm{Zn}-\mathrm{Cu}-\mathrm{Pb}$ deposit located on the DRC side of the border. The exploration ground has poor rock exposure which hamper geological mapping, hence the geology and stratigraphy maps are mainly based on interpretation from geophysical and drilling datasets. Conventional surface soil geochemical multi-element assays were utilised to help map the interpreted stratigraphy of the area via Machine Learning (ML) algorithms in KNIME Analytics Platform. The process involved attributing a $100 \mathrm{~m} \times 400 \mathrm{~m}$ grid of soil data points by stratigraphy using the interpreted local stratigraphy map. Random Forest and Gradient Boosted Tree algorithms were applied to a classbalanced training dataset. Immobile trace elements ( $\mathrm{Ti}, \mathrm{Zr}, \mathrm{Al}, \mathrm{Y}$, $\mathrm{Nd}, \mathrm{Th}, \mathrm{Nb}, \mathrm{Sc} \mathrm{Hf} \mathrm{Ta}$ ) and other elements (As, Cr, V, P, Mo, Sb) were selected as predictor variables to create a supervised model from the training data. The learned algorithms were applied to the rest of the dataset in order to make predictions on stratigraphy-related geochemical patterns.

Results highlighted areas that could potentially be reclassified based on the predicted stratigraphy with high probability. This could provide improved stratigraphic interpretations for the purposes of exploration and targeting. 